\title{
Analisis Faktor Yang Mempengaruhi Perilaku Nasabah Perbankan Konvensional Beralih Ke Perbankan Syariah (Studi Empiris Pada Mahasiswa Perguruan Tinggi di D.I.Y) Ilham Maulana Saud ${ }^{1}$, Iman Teguh ${ }^{2}$, Peni Nugraheni ${ }^{3}$
}

Fakultas Ekonomi dan Bisnis, Universitas Muhammadiyah Yogyakarta

\author{
A R T I C L E I N F O \\ Article history: \\ Received 23 Juli 2018 \\ Revised 22 November 2018 \\ Accepted 30 November 2018
}

Key words:

Accessibility, Extra Curricular Islamic Program, and Customer Behavior of Brand Switching.

\begin{abstract}
A B S T R A C T
This study aims to analyze and prove empirically the influence of knowledge, religiosity, accessibility, and extra curricular islamic program to conventional banking customer behavior that switch to sharia banking. The subjects of this study are students of accounting study programs that become conventional banking customers and switch to sharia banking, whether really switching or not really switching. The object of this study is the institutions of college in the Special Region of Yogyakarta. In this study the sample of 82 respondents selected using purposive sampling method. The analysis used in this research is multiple linear regression analysis using SPSS 24.0. Based on the analysis that has been done obtained the result that the knowledge and extra curricularislamic program does not affect the behavior of conventional banking customers to switch to sharia banking. While religiosity and accessibility proved to have a positive and significant effect.
\end{abstract}

\begin{abstract}
A B S T R A K
Penelitian ini bertujuan untuk menganalisis dan membuktikan secara empiris pengaruh pengetahuan, religiusitas, aksesibilitas, dan program ekstra kurikuler islami terhadap perilaku nasabah perbankan konvensional yang beralih ke perbankan syariah. Subjek penelitian ini adalah mahasiswa program studi akuntansi yang menjadi nasabah perbankan konvensional dan beralih ke perbankan syariah, baik yang beralih secara penuh atau tidak beralih secara penuh. Objek penelitian ini adalah beberapa institusi perguruan tinggi di Daerah Istimewa Yogyakarta. Dalam penelitian ini sampel berjumlah 82 responden yang dipilih menggunakan metode purposive sampling. Analisis yang digunakan dalam penelitian ini adalah Analisis Regresi linier berganda menggunakan SPSS 24.0. Berdasarkan analisis yang telah dilakukan diperoleh hasil bahwa pengetahuan dan program ekstra kurikuler islami tidak berpengaruh terhadap perilaku nasabah perbankan konvensional untuk beralih ke perbankan syariah. Sedangkan religiusitas dan aksesibilitas terbukti berpengaruh positif dan signifikan.
\end{abstract}

\section{INTRODUCTION}

Perkembangan industri perbankan syariah di Indonesia semakin memiliki landasan hukum yang memadai semenjak diberlakukannya UU No. 21 Tahun 2008 tentang Perbankan Syariah yang telah mendorong pertumbuhannya secara lebih cepat lagi. Melihat perkembangan aset produktif berdasarkan kualitas bank umum syariah (BUS) dan unit usaha syariah (UUS) yang mencapai pertumbuhan aset produktif sekitar hampir mencapai $20 \%$ pertahun dalam dua tahun terakhir, maka diharapkan industri perbankan syariah semakin mendukung perekonomian nasional secara berkesinambungan seperti yang ditunjukan pada tabel 1 .

Pada tabel 1 dapat dilihat bahwa terjadi peningkatan total aset produktif perbankan setiap tahunnya dalam dua tahun terakhir. Pada tahun 2014, total aset produktif yang dimiliki perbankan syariah yang merupakan gabungan dari bank umum syariah dan unit usaha syariah yaitu 249.560 miliar. Angka tersebut meningkat pada tahun 2015 menjadi 270.735 miliar atau mencapai $8,48 \%$. Tidak hanya cukup sampai disitu saja,

\footnotetext{
* Corresponding author, email address: ${ }^{1}$ ilhammaulanasaud@gmail.com.
} 
peningkatan yang melebihi dua kali lipatnya ditunjukan pada tahun berikutnya yaitu tahun 2016 yang mencapai $19,69 \%$ atau tepatnya pada angka 324.034 miliar. Peningkatan aset pada bank umum syariah (BUS) dan unit usaha syariah (UUS) ini merupakan salah satu indikator kinerja, hal tersebut menunjukkan bahwa kinerja bank umum syariah dan unit usaha syariah yang baik dan meningkat (Kusumo, 2008)..

Tabel 1. Perkembangan Aset Produktif Berdasarkan Kualitas - Bank Umum Syariah dan Unit Usaha Syariah (miliar) Tahun 2014-2016

\begin{tabular}{|l|c|c|c|}
\hline Indikator & $\mathbf{2 0 1 4}$ & $\mathbf{2 0 1 5}$ & $\mathbf{2 0 1 6}$ \\
\hline Lancar & 227.257 & 241.755 & 295.826 \\
\hline $\begin{array}{l}\text { Dalam } \\
\text { perhatian } \\
\text { khusus }\end{array}$ & 13.406 & 19.507 & 17.680 \\
\hline $\begin{array}{l}\text { Kurang } \\
\text { lancar }\end{array}$ & 2.474 & 2.417 & 3.015 \\
\hline Meragukan & 1.072 & 924 & 1.326 \\
\hline Macet Aset & 4.721 & 6.132 & 7.062 \\
\hline $\begin{array}{l}\text { Total Aset } \\
\text { Produktif }\end{array}$ & 249.560 & 270.735 & 324.034 \\
\hline $\begin{array}{l}\text { Rasio Aset } \\
\text { Produktif } \\
\text { non-Lancar }\end{array}$ & 3,57 & 3,50 & 3,25 \\
\hline
\end{tabular}

Sumber: Statistik Perbankan Syariah, Januari 2017

Peningkatan kinerja perbankan syariah dapat dipengaruhi oleh beberapa faktor, salah satunya adalah peningkatan aktivitas pembiayaan perbankan syariah yang ditunjang oleh peningkatan dana pihak ketiga. Pendanaan yang berasal dari masyarakat yang disimpan di bank merupakan sumber dana terbesar yang paling diandalkan bank yang terdiri dari tiga jenis yaitu giro, deposito, dan tabungan (Qolby, 2013). Peningkatan jumlah dana yang dihimpun dari masyarakat tersebut disebabkan oleh loyalitas pelanggan yang selaras dengan kepuasan pelanggan, Selain itu dipengaruhi juga oleh bertambahnya jumlah nasabah perbankan syariah termasuk nasabah yang beralih dari perbankan konvensional ke perbankan syariah (Hidayat, 2009).

Peningkatan jumlah nasabah perbankan syariah dipengaruhi oleh meningkatnya minat masyarakat untuk menjadi nasabah bank syariah tidak terkecuali mahasiswa. Mahasiswa merupakan salah satu lapisan masyarakat yang banyak menggunakan jasa perbankan, termasuk perbankan syariah. Faktor-faktor yang mempengaruhi mahasiswa untuk menjadi nasabah perbankan syariah berkaitan dengan ruang lingkup mahasiswa di perguruan tinggi seperti: pengetahuan, program ekstra kurikuler Islami, religiusitas, dan aksesibilitas perbankan syariah.

Seseorang yang mendapatkan fakta dan informasi baru dengan menggunakan pengetahuan yang merupakan suatu faktor penting dalam membentuk tindakan seseorang. Pengetahuan yang berkaitan dengan perbankan syariah akan mempengaruhi seorang nasabah (Faisal, 2016). Nasabah yang memahami informasi yang cukup maka akan tertarik menggunakan jasa perbankan syariah.

Dalam Islam, perilaku nasabah memilih perbankan tentunya dipengaruhi oleh akhlak setiap nasabah. Sejatinya, nasabah yang memiliki akhlak yang baik akan memilih perbankan syariah sebagai mitranya. Oleh sebab itu, pendidikan akhlak sangat penting bagi umat muslim dalam rangka memperbaiki diri menjadi muslim yang sebenar-benarnya (Ilyas, 2014).

Perilaku mahasiswa dalam hal menjadi nasabah perbankan syariah tidak menutup kemungkinan dipengaruhi oleh religiusitas mahasiswa. Religiusitas menurut agama Islam adalah menjalankan ajaran agama secara menyeluruh. Religiusitas merupakan tingkat keterikatan individu terhadap agamanya. Apabila individu telah menghayati dan menginternalisasikan ajaran agamanya, maka ajaran agama akan berpengaruh dalam segala tindakan dan pandangan hidupnya (Ghufron dan Risnawita, 2010). Hasil penelitian Dianto (2016) menunjukkan bahwa religiusitas berpengaruh terhadap minat masyarakat untuk menjadi nasabah bank syariah.

Aksesibilitas perbankan syariah sangat berkorelasi dengan lokasi perbankan syariah, karena pada dasarnya salah satu faktor yang dipertimbangan dalam penentuan lokasi perbankan adalah lokasi yang mudah dijangkau atau dalam kata lain memiliki aksesibilitas yang baik. Sebagaimana hasil penelitian Pertiwi dan Ritonga (2012) menunjukkan bahwa lokasi bank mempengaruhi masyarakat di kota Kisaran untuk menabung dibank Muamalat.

Penelitian ini merupakan penelitian yang bersifat kompilasi yang mengambil beberapa variabel yang sesuai dari penelitian-penelitian sebelumnya yaitu penelitian Faisal (2016), Penelitian Hendiyana (2015), Penelitian Dianto (2016), dan Penelitian Maesaroh (2014). 
Perbedaan penelitian ini dengan penelitian terdahulu adalah memasukkan variabel program ekstra kurikuler Islami dan subyek penelitiannya adalah mahasiswa program studi akuntansi. Selain itu, penelitian ini menggunakan variabel perilaku konsumen berpindah merek sebagai variabel dependen, sedangkan penelitian sebelumnya menggunakan variabel minat.

Penelitian terhadap perilaku konsumen berpindah merek dalam penelitian ini berkaitan dengan salah satu bentuk upaya masyarakat muslim dalam konteks nasabah untuk melakukan perbaikan dalam menegakkan nilai-nilai syariah dalam hal ekonomi yaitu dengan beralih dari lembaga keuangan konvensional ke lembaga keuangan syariah. Hal tersebut sangat erat kaitannya dengan perilaku yang merupakan hasil refleksi sebuah sinergi antara kekuatan eksternal dan internal sebagaimana dijelaskan dalam teori atribusi yang pada intinya setiap tindakan atau ide yang akan dilakukan oleh seorang individu akan dipengaruhi oleh faktor internal dan faktor eksternal individu tersebut (Luthans, 2005). Dalam penelitian ini faktor eksternal dan faktor internal tersebut telah diwakili oleh variabel independen yang digunakan yaitu pengetahuan, religiusitas, program ekstra kurikuler Islami dan aksesibilitas.

Tujuan penelitian ini adalah untuk membuktikan secara empiris faktor eksternal dan faktor internal yang diduga mampu mempengaruhi mahasiswa akuntansi dalam konteks nasabah yang beralih dari perbankan konvensional ke perbankan syariah. Jika faktanya variabel independen yang telah ditentukkan terbukti secara empiris mampu mempengaruhi perilaku mahasiswa akuntansi untuk beralih dari perbankan konvensional ke perbankan syariah, maka hasil penelitian ini diharapkan mampu memberikan masukan untuk institusi perguruan tinggi khususnya program studi akuntansi dalam hal peningkatan mutu sehingga mampu melahirkan sumber daya-sumber daya yang lebih berkualitas dan mampu menunjang prospek lembaga keuangan syariah sebagaimana yang diharapkan oleh masyarakat muslim untuk memenuhi kebutuhannya dalam bertransaksi.

\section{THEORETICAL FRAMEWORK AND HYPOTHESES \\ Teori Atribusi}

Teori atribusi adalah teori yang menjelaskan perilaku seseorang. Teori atribusi menjelaskan proses bagaimana seseorang menentukan penyebab dan motif tentang perilaku seseorang atau orang lain. Teori ini mengacu pada bagaimana seseorang menjelaskan faktor penyebab perilaku orang lain atau bahkan dirinya sendiri. Faktor tersebut bisa berasal dari internal seperti sifat, karakter, sikap, dan lain sebagainya atau yang berasal dari eksternal misalnya tekanan situasi tertentu yang akan memberikan pengaruh terhadap perilaku individu (Luthans, 2005 ). Dalam penelitian ini, variabel pengetahuan, aksesibilitas, program intra kurikuler Islami, dan religiusitas dapat mewakili faktor eksternal dan internal yang berpengaruh terhadap perilaku individu untuk berpindah dari nasabah perbankan konevnsional ke nasabah perbankan syariah.

\section{Pengaruh Pengetahuan terhadap Perilaku Nasabah Perbankan Konvensional Beralih ke Perbankan Syariah \\ Dalam institusi perguruan tinggi mahasiswa} diampu dalam suatu sistem perkuliahan yang terdiri dari macam-macam mata kuliah. Idealnya, mahasiswa yang telah selesai menempuh suatu mata kuliah tertentu mampu mengaplikasikan pengetahuan serta kemampuan yang telah dilatih saat menempuh mata kuliah tersebut tidak terkecuali mata kuliah akuntansi syariah. Dalam mata kuliah ini serta mata kuliah pendukung lainnya, mahasiswa mendapatkan pengetahuan tentang sistem akuntansi yang berbasis syariah, serta korelasinya dengan perbankan syariah. Disamping itu mahasiswa akan mendapatkan pemahaman tentang penyebab lahirnya sistem akuntansi dan perbankan yang berbasis syariah yang tidak lain merupakan solusi bagi sistem perekonomian umat muslim dari jeratan riba yang terdapat dalam sistem perbankan konvensional.Penelitian yang dilakukan oleh Lestari (2014) menunjukkan bahwasannya pengetahuan berpengaruh positif signifikan terhadap preferensi menabung di bank syariah. Selain itu, hasil penelitian Dianto (2016) juga menunjukkan bahwa terdapat pengaruh pengetahuan terhadap minat masyarakat untuk menjadi nasabah perbankan syariah.

Penelitian yang serupa telah dilakukan oleh Rahmawati (2014) dengan hasil penelitian yang menunjukkan bahwa persepsi tentang bunga bank dan persepsi tentang bagi hasil berpengaruh positif dan signifikan terhadap minat menggunakan produk perbankan syariah, sedangkan persepsi dan pengetahuan terhadap produk perbankan syariah tidak berpengaruh terhadap minat 
menggunakan produk bank syariah. Pengetahuan dan pemahaman tentang larangan bunga bank konvensional, sistem bagi hasil, serta pengatahuan tentang produk bank syariah telah dikaji dalam mata kuliah akuntansi syariah. Sejalan dengan pendapat Kariyoto (2013) bahwasannya akuntansi syariah lahir dari adanya kebutuhan lembaga keuangan syariah untuk menyajikan laporan keuangan ataupun informasi keuangan yang cukup, relevan, serta selaras dengan prinsip ekonomi Islam.

Berdasarkan uraian tersebut, dapat dipahamii bahwa semakin tinggi pengetahuan mahasiswa tentang segala sesuatu yang berkorelasi dengan perbankan syariah, maka semakin tinggi pengaruhnya terhadap perilaku mahasiswa yang merupakan nasabah perbankan konvensional untuk beralih ke perbankan sayriah. Oleh sebab itu, hipotesis pertama dalam penelitian ini yaitu:

$\mathrm{H}_{1}$ : Pengetahuan berpengaruh positif terhadap perilaku nasabah perbankan konvensional beralih ke perbankan syariah.

\section{Pengaruh Religiusitas terhadap Perilaku Nasabah Perbankan Konvensional Beralih ke Perbankan Syariah}

Persoalan mengenai larangan riba telah lama dilarang dalam beberapa agama tidak hanya agama Islam (Antonio, 2016). Seorang nasabah yang beragama Islam jika memiliki tingkat religiusitas yang baik maka akan menghindari bahaya dan ancaman bagi pemakan riba sebagaimana ancaman terberat bagi pemakan riba dalam Al-Qur'an bahwasannya Allah dan RasulNya akan memeranginya.

Hasil penelitian Dianto (2016) menunjukkan bahwa terdapat pengaruh religiusitas terhadap minat nasabah untuk menjadi nasabah bank syariah. Penelitian serupa juga dilakukan oleh Widiyanti (2011) menunjukkan hasil bahwa faktor komitmen keagamaan berpengaruh secara positif dan signifikan terhadap minat mahasiswa berinvestasi di bank syariah. Akan tetapi, hasil sebaliknya ditunjukkan dalam penelitian Risky (2015) bahwasannya faktor religiusitas tidak berpengaruh secara signifikan. Hasil penelitian Sunarsih dan Wulandari (2014) juga menunjukkan hasil serupa yaitu faktor religiusitas tidak berpengaruh untuk kepentingan nasabah Bank Muamalat, Rawamangun Jakarta. Berdasarkan uraian tersebut dapat dipahami bahwa semakin tinggi religiusitas mahasiswa, maka akan semakin mempengaruhi perilaku mahasiswa yang merupakan nasabah perbankan konvensional untuk beralih ke perbankan syariah. Oleh sebab itu, hipotesis kedua dalam penelitian ini yaitu:

$\mathrm{H}_{2}$ : Religiusitas berpengaruh positif terhadap perilaku nasabah perbankan konvensional beralih ke perbankan syariah.

\section{Pengaruh Aksesibilitas terhadap Perilaku Nasabah Perbankan Konvensional Beralih ke Perbankan Syariah}

Sebagai mahasiswa yang juga merupakan nasabah dari suatu perbankan, besar kemungkinan akan berpindah pada perbankan yang dianggap memiliki aksesibilitas yang baik. Baik itu terkait dengan lingkungan tempat tinggal barunya semenjak menjadi mahasiswa, lokasi perbankan yang berada di lingkungan perguruan tinggi, atau bahkan akasesibilitas tersebut dianggap mampu menunjang kebutuhan terkait dengan kepentingan akademik. Sehingga besar kemungkinan aksesibilitas suatu perbankan akan mempengaruhi perilaku mahasiswa untuk beralih perbankan termasuk nasabah perbankan konvensional yang beralih ke perbankan syariah.

Hasil penelitian Pertiwi dan Ritonga (2012) menunjukkan bahwa lokasi bank mempengaruhi masyarakat di Kota Kisaran untuk menabung pada bank muamalat. Hasil yang sama ditunjukkan oleh Tyas dan Setiawan (2012) dalam penelitiannya yang mana lokasi perbankan berpengaruh positif terhadap keputusan nasabah menabung di BMT Sumber Mulia. Akan tetapi hasil yang sebaliknya ditunjukkan dalam penelitian Arifin dan Khotimah (2014) bahwasannya lokasi bukanlah hal yang mempengaruhi masyarakat Kota Surakarta untuk memutuskan menjadi nasabah Bank Syariah. Berdasarkan uraian tersebut dapat ditarik kesempulan bahwa semakin tinggi aksesibilitas mahasiswa terhadap perbankan syariah, maka semakin besar pengaruhnya terhadap perilaku mahasiswa yang merupakan nasabah perbankan konvensional untuk beralih ke perbankan sayriah. Oleh sebab itu, hipotesis penelitian ketiga dalam penelitian ini yaitu:

$\mathrm{H}_{3}$ : Aksesibilitas berpengaruh positif terhadap perilaku nasabah perbankan konvensional beralih ke perbankan syariah.

\section{Pengaruh Program Ekstra Kurikuler Islami terhadap Perilaku Nasabah Perbankan Konvensional Beralih ke Perbankan Syariah}

Dalam konteks nasabah, jika program ekstra kurikuler Islami, mentoring, dan program pendidikan akhlak lainnya yang serupa dapat 
mempengaruhi akhlak dan perilaku keagamaan mahasiswa atau peserta didik menuju ke arah yang lebih baik maka senantiasa sebagai nasabah idealnya akan memilih produk perbankan yang sesuai dengan nilai keagamaan yang diyakininya. Bahkan, jika sebelumnya menggunakan produk perbankan yang tidak sesuai dengan nilai keagamaan yang diyakininya, idealnya akan berpindah ke produk yang sesuai dengan nilai keagamaan yang diyakininya.

Sejalan dengan pendapat Ruswandi (2007) yang menjelaskan bahwa program ekstra kurikuler Islami merupakan program pembinaan keislaman yang didalamnya terdapat proses mentoring atau belajar dengan pendekatan saling menasihati dengan tujuan utama untuk pendidikan akhlak yang berguna dalam beribadah dan muamalah serta guna membantu mencapai tujuan suatu institusi pendidikan. Penelitian yang dilakukan oleh Hendiyana (2015) menunjukkan hasil bahwa kegiatan mentoring terbukti berpengaruh positif signifikan terhadap akhlak siswa sehingga dapat membentuk akhlakul karimah.

Penelitian lain menunjukkan hasil bahwa tingkat hubungan antara kedisiplinan mengikuti kegiatan mentoring terhadap akhlak adalah sangat kuat (Astutik, 2015). Selain itu, penelitian yang dilakukan oleh Fatimah (2014) menunjukkan hasil bahwa terdapat pengaruh keaktifan mengikuti kegiatan mentoring terhadap kedisiplinan beribadah. Akan tetapi, hasil kegiatan mentoring agama Islam memang berpengaruh positif terhadap perilaku sosial keagamaan dengan taraf kepercayaan 95\% namun kontribusi efektifnya hanya sebesar 10,9\% (Latifah, 2016). Berdasarkan uraian tersebut dapat dipahami bahwa program ekstra kurikuler Islami akan membentuk akhlak mahasiswa, sehingga dalam konteks nasabah mahasiswa yang merupakan nasabah perbankan konvensional akan beralih ke perbankan syariah. Oleh sebab itu, hipotesis keempat dalam penelitian ini yaitu:

$\mathrm{H}_{4}$ : Program intra kurikuler Islami berpengaruh positif terhadap perilaku nasabah perbankan konvensional beralih ke perbankan syariah.

\section{RESEARCH METHOD}

Sampel dalam penelitian ini adalah mahasiswa program studi akuntansi Universitas Muhammadiyah Yogyakarta (UMY), Universitas Islam Negeri (UIN) Sunan Kalijaga, Universitas Islam Indonesia (UII), Universitas Negeri Yogyakarta (UNY), Universitas Gajah Mada
(UGM), dan Akademi Akuntansi Yayasan Keluarga Pahlawan Negara (YKPN). Jenis data yang digunakan adalah data primer. Data primer dalam penelitian ini diperoleh menggunakan instrumen kuisioner dari para responden yang kemudian dikonversi kedalam bentuk angka (kuantitatif) sehingga analisis data bisa menggunakan data statistik. Kuisioner tersebut berisi daftar pertanyaan mengenai pengetahuan, program intra kuriruler Islami, religiusitas, dan perilaku nasabah perbankan konvensional beralih ke perbankan syariah. Dalam penelitian ini, teknik pengambilan sampel dilakukan dengan menggunakan teknik purposive sampling. Penentuan sampel didasarkan pada kriteria, yaitu mahasiswa yang merupakan mantan nasabah perbankan konvensional, sekaligus merupakan nasabah perbankan syariah; mahasiswa yang merupakan nasabah kedua jenis perbankan (konvensional dan syariah), akan tetapi telah menjadi nasabah perbankan konvensional terlebih dahulu baru kemudian menjadi nasabah perbankan syariah.

Tabel 2. Karakteristik Data Berdasarkan Hasil Pengisian Kuesioner

\begin{tabular}{|c|c|c|}
\hline Keterangan & Jumlah & Presentase \\
\hline Kuesioner terkumpul & $\mathbf{3 5 3}$ & $\mathbf{1 0 0 \%}$ \\
\hline Kuesioner online & 162 & $46 \%$ \\
\hline Kuesioner cetak & 191 & $54 \%$ \\
\hline $\begin{array}{l}\text { Kuesioner tidak } \\
\text { memenuhi kriteria }\end{array}$ & $\mathbf{2 7 1}$ & $\mathbf{7 7 \%}$ \\
\hline Kuesioner online & 114 & $33 \%$ \\
\hline Kuesioner cetak & 157 & $44 \%$ \\
\hline $\begin{array}{l}\text { Kuesioner memenuhi } \\
\text { kriteria }\end{array}$ & $\mathbf{8 2}$ & $\mathbf{2 3 \%}$ \\
\hline Kuesioner online & 48 & $13 \%$ \\
\hline Kuesioner cetak & 34 & $10 \%$ \\
\hline \multicolumn{2}{|c|}{}
\end{tabular}

Teknik pengumpulan data menggunakan teknik survei dengan instrumen kuesioner yang terbagi kedalam dua metode, yaitu metode langsung dan metode kuesioner online menggunakan google form. Survei dilakukan pada bulan Januari 2018 sampai bulan Maret 2018. Peneliti berhasil mengumpulkan data sebanyak 162 kuesioner dari survei yang bersifat online, dan 191 kuesioner dari survei yang bersifat langsung. Dari total 353 kuesioner, peneliti berhasil mengumpulkan data yang memenuhi kriteria sebanyak 82 kuesioner yang dapat diolah, sedangkan 271 kuesioner lainnya 
tidak memenuhi kriteria. Dari 82 kuesioner yang memenuhi kriteria, 48 kuesioner diperoleh dari bersifat langsung. survei online, dan 34 lainnya dari survei yang

Tabel 3 Hasil Uji Statistik Deskriptif

\begin{tabular}{|l|c|c|c|c|c|c|c|c|}
\hline \multirow{2}{*}{ Variabel } & \multirow{2}{*}{$\mathbf{N}$} & \multicolumn{3}{|c|}{ Kisaran Teoritis } & \multicolumn{3}{c|}{ Kisaran Aktual } & \multirow{2}{*}{ Std. Deviation } \\
\cline { 3 - 8 } & & Min & Max & Mean & Min & Max & Mean & \\
\hline PKBM & 82 & 3 & 15 & 9 & 6 & 15 & 10.45 & 2.206 \\
\hline PG & 82 & 5 & 25 & 14.50 & 16 & 25 & 21.70 & 2.308 \\
\hline RL & 82 & 6 & 30 & 18 & 14 & 30 & 22.63 & 3.376 \\
\hline AS & 82 & 4 & 20 & 12 & 6 & 20 & 12.77 & 3.191 \\
\hline PEKI & 82 & 0 & 1 & 0.50 & 0 & 1 & 0.74 & 0.439 \\
\hline
\end{tabular}

\section{DATA ANALYSIS AND DISCUSSION Uji Validitas dan Uji Reliabilitas}

Uji validitas berguna untuk mengetahui valid atau tidaknya kuisioner. Kuisioner dinyatakan valid jika kuisioner dapat digunakan untuk mengukur apa yang seharusnya diukur. Reliabilitas menunjukkan konsistensi dan stabilitas dari suatu skor (skala pengukuran). Reliabilitas mencakup dua hal yang utama yaitu stabilitas dan konsistensi internal dari pengukuran. Suatu instrumen kuesioner dinyatakan reliabel jika diujicobakan secara berulang-ulang pada kelompok yang sama cenderung menghasilkan data yang tidak jauh berbeda.

Hasil uji validitas semua item pertanyaan variabel pada penelitian menunjukkan nilai component matrix $>0,7$ dengan nilai $\mathrm{KMO}>0,5$. Sedangkan, hasil uji reliabilitas pada penelitian ini menunjukkan jika nilai cronbach alpha $>0,70$. Hal ini menunjukkan bahwa instrumen pada penelitian ini dapat dinyatakan valid dan reliable, sehingga dapat dilakukan untuk analisis uji selanjutnya.

\section{Statistik Deskriptif}

Statistik deskriptif pada penelitian ini menyajikan jumlah data, nilai minimum, nilai maksimum, nilai rata-rata (mean) dan simpangan baku (standar deviation) dari variabel independen dan variabel dependen. Hasil statistik deskriptif ditunjukkan dalam tabel 3 dibawah ini:

Berdasarkan data yang dimuat dalam tabel 3 di atas, menunjukkan bahwa data dalam penelitian ini sebanyak 82 sampel. Variabel pengetahuan $\left(X_{1}\right)$ memiliki nilai minimum 16; nilai maksimum 25; nilai rata-rata (mean) 21,70; dan simpangan baku (standard deviation) 2,206. Jika dibandingkan dengan nilai yang terdapat pada kisaran teoritis yang memiliki nilai rata-rata (mean) 14,50, maka hal ini menunjukkan tingkat pengetahuan yang dimiliki oleh responden cukup tinggi. Variabel religiusitas $\left(X_{2}\right)$ memiliki nilai minimum 14; nilai maksimum 30; nilai rata-rata (mean) 22,63; dan simpangan baku (standard deviation) 3,376. Jika dibandingkan dengan nilai yang terdapat pada kisaran teoritis yang memiliki nilai rata-rata (mean) 18, maka hal ini menunjukkan bahwa tingkat religiusitas responden dalam hal menjadi nasabah cukup kuat.

Variabel aksesibilitas $\left(\mathrm{X}_{3}\right)$ memiliki nilai minimum 6; nilai maksimum 20; nilai rata-rata (mean) 12,77; dan simpangan baku (standard deviation) 3,191. Jika dibandingkan dengan nilai yang terdapat pada kisaran teoritis yang memiliki nilai rata-rata (mean) 12, maka hal ini menunjukkan bahwa rata-rata responden mampu menjangkau fasilitas dan pelayanan yang diberikan oleh perbankan syariah dengan cukup mudah. Variabel program ekstra kulikuler islami (PEKI) $\left(\mathrm{X}_{4}\right)$ memiliki nilai minimum 0; nilai maksimum 1; nilai rata-rata (mean) 0,74 ; dan simpangan baku (standard deviation) 0,439. Jika dibandingkan dengan nilai yang terdapat pada kisaran teoritis yang memiliki nilai rata-rata (mean) 0,50, maka hal ini menunjukkan bahwa mayoritas responden telah mengikuti program ekstra kurikuler islami di masing-masing institusi perguruan tinggi.

Variabel perilaku konsumen berpindah merek (PKBM) (Y) memiliki nilai minimum 6; nilai maksimum 15; nilai rata-rata (mean) 10,45; dan simpangan baku (standard deviation) 2,206. Jika dibandingkan dengan nilai yang terdapat pada kisaran teoritis yang memiliki nilai rata-rata (mean) 9, maka hal ini menunjukkan bahwa ratarata responden telah beralih dari perbankan konvensional ke perbankan syariah baik beralih secara penuh maupun baru sebatas 
memprioritaskan perbankan syariah.

\section{Uji Frekuensi}

Uji frekuensi dilakukan untuk mengetahui beberapa informasi terkait variabel dummy. Program ekstra kurikuler islami (PEKI) diukur dengan skor dummy yaitu 0 - 1, informasi hasil uji fekuensi nya ditunjukkan dalam tabel 4.

Tabel 4 Hasil Uji Frekuensi

\begin{tabular}{|c|c|c|}
\hline & Frequensi & Persentase \\
\hline Non_PEKI & 21 & 25.6 \\
\hline PEKI & 61 & 74.4 \\
\hline Total & 82 & 100.0 \\
\hline
\end{tabular}

Berdasarkan data dalam tabel 4 diatas, dapat diketahui bahwa dari total 82 responden. Responden yang tidak mengikuti program ekstra kurikuler islami (Non_PEKI) hanya berjumlah 21 orang, sedangkan responden yang mengikuti program ekstra kurikuler islami (PEKI) mencapai 61 orang.

\section{Uji Normalitas Data}

Uji normalitas dilakukan untuk memastikan bahwa model regresi variabel dependen dan independen keduanya berdistribusi normal, karena regresi yang baik sejatinya berdistribusi normal. Tujuan dari uji normalitas data ini adalah untuk mengetahui apakah data yang diperoleh berdasarkan hasil penelitian telah berdistribusi normal atau tidak. Pada penelitian ini, uji normalitas data dilakukan dengan uji kolmogorovsmirnov.

Data dapat dikatakan berdistribusi normal jika nilai Asymp. Sig. (2-tailed) lebih dari atau sama dengan 0,05 atau 5\%. Berdasarkan data yang ditunjukkan pada tabel 5, Hasil uji normalitas data dengan menggunakan kolmogorov-sirnov test ini menghasilkan nilai Asymp. Sig. (2-tailed) sebesar $0,200>0,05$ atau $20 \%>5 \%$. Maka dapat disimpulkan bahwa data yang digunakan dalam penelitian ini telah berdistribusi normal.

Tabel 5 Hasil Uji Normalitas Data

\begin{tabular}{|l|l|r|}
\hline $\mathrm{N}$ & Mean & 82 \\
\hline \begin{tabular}{l} 
Normal \begin{tabular}{l} 
Parameters $\mathrm{a}, \mathrm{b}$ \\
\cline { 2 - 3 }
\end{tabular} \\
\cline { 2 - 3 } $\begin{array}{l}\text { Most Extreme } \\
\text { Differences }\end{array}$
\end{tabular} & $\begin{array}{l}\text { Deviation } \\
\text { Absolute }\end{array}$ \\
\cline { 2 - 3 } & Positive & .000 \\
\cline { 2 - 3 } & Negative & .066 \\
\hline Test Statistic & .048 \\
\hline Asymp. Sig. (2-tailed) & .066 \\
\hline
\end{tabular}

\section{Uji Multikolinieritas}

Multikolinieritas sejatinya menunjukkan adanya hubungan antar variabel independen atau variabel yang menjelaskan. Model ini mensyaratkan memenuhi asumsi bahwa tidak ada hubungan antar variabel tersebut artinya tidak terdapat multikolinieritas. Indikator yang digunakan untuk mendeteksi ada atau tidaknya multikolinieritas mengacu pada nilai VIF (Variance Inflation Factor) dan tolerance. Jika nilai VIF $<10$ atau tolerance $>0,10$ maka tidak terdapat multikolinieritas diantara variabel independen yang digunakan. Hasil uji mutikolinieritas dalam penelitian ini disajikan dalam tabel 6 .

Tabel 6 Hasil Uji Multikolinieritas

\begin{tabular}{|l|c|c|}
\hline \multicolumn{1}{|c|}{ Variabel } & Tolerance & VIF \\
\hline PG & 0.788 & 1.285 \\
\hline RL & 0.707 & 1.415 \\
\hline AK & 0.886 & 1.128 \\
\hline PEKI & 0.933 & 1.072 \\
\hline
\end{tabular}

Berdasarkan pada data yang dimuat dalam tabel 6 diatas, dapat diketahui bahwa variabel pengetahuan memiliki nilai VIF 1,285 < 10 maka data variabel tersebut tidak terjadi multikolinearitas. Variabel religiusitas memiliki nilai VIF $1,415<10$ artinya data dalam variabel tersebut tidak terkena multikolinearitas. Variabel aksesibilitas menunjukkan nilai VIF 1,128 < 10 maka data pada variabel tersebut tidak terkena multikolinearitas.

Program ekstra kulikuler islami (PEKI) sebagai variabel dependen ke empat menunjukkan nilai VIF $1,072<10$ yang berarti data dalam variabel tersebut tidak terkena multikolinearitas. Berdasarkan pada penjelasan tersebut, dapat disimpulkan bahwa setiap variabel yang digunakan dalam penelitian ini menunjukkan nilai VIF < 10, oleh sebab itu dapat disimpulkan bahwa dalam penelitian ini tidak terjadi multikolinearitas.

\section{Uji Heteroskedastisitas}

Heteroskedastisitas dapat didefinisikan sebagai indikator terdapatnya varian yang berbeda dari unsur gangguan (disturbance) sedangkan syarat asumsi klasik yang harus terpenuhi adalah data bersifat homogen, varian dari unsur tersebut harus konstan. Varian atau data dapat dikatakan tidak terkena heteroskedastisitas apabila nilai sig lebih besar atau sama dengan 0,05 atau 5\%. Hasil uji heteroskedastisitas yang dilakukan dalam penelitian ini disajikan dalam tabel 7 . 

Tabel 7 Hasil Uji Heteroskedastisitas

\begin{tabular}{|l|c|c|c|c|c|}
\hline & B & Std. Error & Beta & T & Sig \\
\hline Constant & -0.112 & 1.136 & & -0.098 & 0.922 \\
\hline PG & 0.046 & 0.055 & 0.105 & 0.830 & 0.409 \\
\hline RL & 0.045 & 0.040 & 0.152 & 1.144 & 0.256 \\
\hline AK & -0.032 & 0.038 & -0.100 & -0.848 & 0.399 \\
\hline PEKI & -0.063 & 0.266 & -0.028 & -0.239 & 0.812 \\
\hline
\end{tabular}

Berdasarkan hasil uji heteroskedastisitas yang disajikan dalam tabel 7 diatas, dapat diketahui bahwa variabel pengetahuan memiliki nilai sig 0,409>0,05 maka tidak terkena heteroskedastisitas. Variabel religiusitas menunjukkan nilai sig 0,256 > 0,05 maka tidak terkena heteroskedastisitas. Variabel aksesibilitas memiliki nilai sig 0,399 > 0,05 maka tidak terkeda heteroskedastisitas. Variabel program ekstras kulikuler islami (PEKI) menunjukkan nilai sig sebesar 0,812 > 0,05 maka tidak terkena heteroskedastisitas. Berdasarkan pada uraian tersebut, dapat disimpulkan bahwa nilai sig dari setiap variabel lebih besar dari 0,05 atau 5\%, maka dalam penelitian ini tidak terjadi heteroskedastisitas.

\section{Uji Hipotesis}

Pengujian ini dilakukan untuk menguji hipotesis dengan melihat nilai koefisien regresi dari setiap variabel independen terhadap variabel dependen dalam arti untuk menguji apakah variabel independen berpengaruh secara parsial terhadap variabel dependen yang telah ditentukan. Berdasarkan hasil perhitungan regresi linier berganda dengan menggunakan SPSS 24.0, diperoleh hasil yang disajikan dalam tabel 7.

Tabel 8 Hasil Uji T (Signifikansi Parsial)

\begin{tabular}{|l|c|c|c|c|c|}
\hline & B & Std. Error & Beta & t & Sig. \\
\hline Cons & 0.591 & 2.049 & & 0.289 & 0.744 \\
\hline PG & 0.061 & 0.100 & 0.063 & 0.607 & 0.545 \\
\hline RL & 0.254 & 0.072 & 0.389 & 3.551 & 0.001 \\
\hline AK & 0.207 & 0.068 & 0.299 & 3.508 & 0.003 \\
\hline PEKI & 0.189 & 0.479 & 0.038 & 0.394 & 0.695 \\
\hline
\end{tabular}

\section{Pembahasan}

Secara garis besar penelitian ini dilakukan untuk mengetahui seberapa besar pengaruh pengetahuan, program ekstra kurikuler islami, religiusitas, dan aksesibilitas perbankan syariah terhadap perilaku konsumen berpindah merek sebagai variabel dependen (dalam hal ini perilaku nasabah perbankan konvensional beralih ke perbankan syariah). Hasil penelitian ini menunjukkan bahwa dari keempat variabel independen hanya dua dari empat variabel yang berpengaruh terhadap perilaku nasabah perbankan konvensional beralih ke perbankan syariah, yaitu variabel religiusitas dan variabel aksesibilitas. Sedangkan dua variabel lainnya yaitu pengetahuan dan program ekstra kurikuler islami dinyatakan tidak berpengaruh terhadap perilaku nasabah perbankan konvensional beralih ke perbankan syariah.

Berdasarkan hasil penelitian mengenai faktor-faktor yang mempengaruhi perilaku nasabah perbankan konvensional beralih ke perbankan syariah diketahui bahwa untuk variabel pengetahuan $\left(X_{1}\right)$ memiliki nilai sig $(0,545)>$ a $(0,05)$ dan arah koefisien regresi positif 0,063 , yang berarti bahwa variabel pengetahuan tidak berpengaruh terhadap perilaku nasabah perbankan konvensional beralih ke perbankan syariah. Hal ini tidak sejalan dengan hasil penelitian yang dilakukan oleh Lestari (2014) dan Dianto (2016) yang masing-masing menunjukkan bahwa pengetahuan berpengaruh positif signifikan terhadap preferensi menabung di bank syariah dan berpengaruh positif signifikan terhadap minat masyarakat untuk menjadi nasabah bank syariah.

Hasil penelitian ini yang menyatakan bahwa pengetahuan tidak berpengaruh terhadap perilaku nasabah perbankan konvensional beralih ke perbankan syariah, yang justru selaras dengan hasil penelitian yang dilakukan oleh Rahmawati (2014) bahwasannya persepsi dan pengetahuan terhadap produk perbankan syariah tidak berpengaruh terhadap minat menggunakan produk bank syariah. Hal ini terjadi diduga karena setelah dianalisa secara lebih mendalam bahwasannya pengetahuan yang dimaksud adalah pengetahuan konsumen atau pengetahuan tentang produk dan jasa yang diberikan (dalam hal ini pengetahuan tentang produk dan jasa yang diberikan oleh bank syariah), dan 
pengetahuan lainnya yang berkorelasi dengan produk dan jasa tersebut (Suwarman, 2004).

Selain itu, responden yang berkontribusi dalam penelitian ini adalah mahasiswa program studi akuntansi. Dari total responden yang memenuhi kriteria, terdapat $75,61 \%$ responden yang telah mengambil mata kuliah akuntansi syariah. Jadi, mayoritas responden memiliki pengetahuan tentang sistem keuangan syariah dan akad-akad syariah yang menjadi dasar dalam produk dan jasa yang ditawarkan oleh perbankan syariah. Responden lainnya yang tidak atau belum mengambil mata kuliah tersebut juga belum tentu tidak memiliki pengetahuan yang memadai mengenai produk dan jasa yang ditawarkan oleh perbankan syariah. Akan tetapi, faktor lain selain dari pengetahuan tentang produk dan jasa yang ditawarkan oleh perbankan syariah lebih berpengaruh secara signifikan terhadap perilaku nasabah perbankan konvensional beralih ke perbankan syariah.

Untuk variabel religiusitas $\left(X_{2}\right)$ memiliki nilai $\operatorname{sig}(0,001)<\alpha(0,005)$ dan arah koefisien regresi positif 0,389 , yang berarti bahwa religiusitas terbukti berpengaruh positif dan signifikan terhadap perilaku nasabah perbankan konvensional beralih ke perbankan syariah. Hasil penelitian ini sejalan dengan hasil penelitian yang dilakukan oleh Abhimantra (2013) dan Widiyanti (2011) yang masing-masing hasil penelitiannya menunjukkan bahwa terdapat pengaruh religiusitas terhadap minat nasabah untuk menjadi nasabah bank syariah dan faktor komitmen keagamaan secara positif dan signifikan terhadap minat mahasiswa berinvestasi di bank syariah.

Hasil penelitian ini yang menunjukkan bahwa religiusitas berpengaruh positif dan signifikan terhadap perilaku nasabah perbankan konvensional beralih ke perbankan syariah, merefleksikan nilai-nilai keagamaan yang telah dihayati dalam hati dan dijalankan secara menyeluruh hingga pada konteks perilaku menjadi nasabah dan berdasar pada hubungan pribadi dengan Tuhan yang berkonsekuensi hasrat untuk berkenan melaksanakan kehendakNya dan menjauhi segala larangan-Nya (Suhardiyanto, 2001).

Untuk variabel aksesibilitas $\left(X_{3}\right)$ memiliki nilai sig $(0,003)<\alpha(0,005)$ dan arah koefisien regresi positif 0,299 , yang berarti aksesibilitas berpengaruh secara positif dan signifikan terhadap perilaku nasabah perbankan konvensional beralih ke perbankan syariah. Hasil penelitian ini sejalan dengen penelitian terdahulu yang dilakukan oleh Pertiwi dan Ritonga (2012) yang menunjukkan bahwa lokasi bank mempengaruhi masyarakat di Kota Kisaran untuk menabung pada bank muamalat. Hasil yang selaras juga ditunjukkan oleh Tyas dan Setiawan (2012) dalam penelitiannya yang mana lokasi perbankan berpengaruh positif terhadap keputusan nasabah menabung di BMT Sumber Mulia.

Hasil penelitian ini yang membuktikan bahwa asksesibilitas berpengaruh terhadap perilaku nasabah perbankan konvensional beralih ke perbankan syariah merefleksikan bahwa adanya faktor eksternal yang mempengaruhi, yaitu derajat kemudahan yang dicapai oleh individu terhadap suatu objek, pelayanan, atau lingkungan (dalam hal ini pelayanan dan lokasi bank syariah). Hasil penelitian ini sekaligus membuktikan bahwa lokasi yang strategis, mudah dijangkau, serta aman telah menjadi prioritas utama bagi para calon konsumen dalam mengambil keputusan untu menggunakan jasa (Jerry, 2000).

Untuk variabel program ekstra kurikuler islami $\left(X_{4}\right)$ memiliki nilai sig $(0,695)>\alpha(0,05)$ dan arah koefisien regresi positif 0,038 , yang berarti bahwa program ekstra kurikuler islami tidak berpengaruh terhadap perilaku nasabah perbankan konvensional beralih ke perabankan syariah. Hasil ponelitian ini tidak sejalan dengan hasil penelitian terdahulu yang telah dilakukan oleh Hendiyana (2015) dan Astutik (2015), yang masing-masing hasil penelitiannya menunjukkan bahwa kegiatan mentoring terbukti berpengaruh positif signifikan terhadap akhlak mahasiswa sehingga membentuk akhlakul karamah dan tingkat hubungan antara kedisiplinan mengikuti kegiatan mentoring terhadap akhlak adalah sangat kuat.

Meskipun dalam hal ini program tersebut tidak berpengaruh, akan tetapi bukan berarti program tersebut tidak bermanfaat untuk diimplementasikan dengan sasaran untuk memperbaiki akhlak, hanya saja dalam penelitian ini sasarannya dalam konteks perilaku nasabah perbankan konvensional beralih ke perbankan syariah belum tercapai atau belum ada pengaruhnya yang mungkin tergantung pada tingkat kedisiplinan dan keaktifan responden dalam mengikuti program tersebut. Sebagaimana hasil penelitian terdahulu yang selaras dengan hasil penelitian ini telah ditunjukkan pada hasil penelitian Fatimah (2014), bahwasannya terdapat 
pengaruh keaktifan mengikuti kegiatan mentoring terhadap kedisiplinan beribadah.

Berdasarkan pada hasil penelitian terdahulu tersebut, dapat disimpulkan bahwa untuk meningkatkan kedisiplinan beribadah memerlukan keaktifan dan kedisiplinan mengikuti program tersebut secara lebih intensif. Demikian juga untuk mencapai sasaran yang lebih jauh sampai pada aspek perilaku dalam muamalah, khususnya dalam konteks menjadi nasabah diduga akan terbukti pengaruhnya secara positif dan signifikan jika diiringi dengan keaktifan dan kedisiplinan mengikuti program tersebut.

Berdasarkan pada uraian tersebut, dapat disimpulkan bahwa dari semua variabel independen yang diteliti dan telah mewakili faktor internal dan eksternal dari teori atribusi dan teori keprilakuan telah terbukti secara empiris dalam mempengaruhi variabel dependennya. Dalam teori atribusi dijelaskan bahwa terdapat perilaku yang berhubungan dengan sikap dan karakteristik individu (Luthans,2005). Selain itu, dalam teori keprilakuan dijelasakan bahwa sikap merupakan kondisi dalam diri seseorang yang mendorong dirinya untuk melakukan suatu tindakan, dan akan menjadi warna pada tingkah laku orang tersebut (Krench, 1983) dalam Maryani dan Ludigdo (2001).

Pembentukan atau perubahan sikap ditentukan oleh dua faktor utama, yaitu faktor internal dan eksternal. Empat variabel yang diteliti telah mewakili faktor internal dan eksternal yang mampu mempengaruhi sikap dalam menentukan perilaku. Hipotesis yang diterima terdiri dari variabel religiusitas (faktor internal), dan variabel aksesibilitas (faktor eksternal) telah bersama-sama menjadi penentu perilaku individu yang merupakan nasabah perbankan konvensional kemudian beralih ke perbankan syariah. Fakta dilapangan yang menunjukkan bahwa terdapat nasabah yang beralih secara penuh dari perbankan konvensional ke perbankan syariah, dan nasabah yang tidak atau belum beralih secara penuh dari perbankan konvensional ke perbankan syariah merefleksikan bahwa faktor internal dan eksternal bersama-sama dengan faktor lain yang tidak diteliti dalam penelitian ini mempengaruhi sikap yang menjadi warna pada tingkah laku setiap individu.

\section{CONCLUSION, IMPLICATION, SUGGES- TION, AND LIMITATIONS \\ Kesimpulan}

Penelitian ini bertujuan untuk membuktikan secara empiris faktor-faktor yang mempengaruhi perilaku nasabah perbankan konvensional beralih ke perbankan syariah. Berdasarkan bukti empiris dari hasil pengujian data dan hasil analisis dalam penelitian ini dapat ditarik kesimpulan. Pertama, variabel pengetahuan dalam penelitian ini tidak ditemukan pengaruhnya terhadap perilaku nasabah perbankan konvensional beralih ke perbankan syariah. Dengan hasil tersebut bukan berarti bahwa responden tidak memiliki pengetahuan tentang produk dan jasa yang diberikan bank syariah, karena terbukti bahwa mayoritas responden yang berkontribusi dalam penelitian ini telah mengambil mata kuliah akuntansi syariah. Akan tetapi, hal tersebut bisa terjadi diduga karena faktor pengetahuan tidak menjadi faktor utama dan bukan satu-satunya faktor yang dijadikan dasar pengambilan keputusan untuk beralih dari perbankan konvensional ke perbankan syariah.

Kedua, variabel religiusitas berpengaruh positig dan signifikan terhadap perilaku nasabah perbankan konvensional beralih ke perbankan syariah. Hal tersebut merefleksikan nilai-nilai keagamaan yang telah dihayati dalam hati dan dijalankan secara menyeluruh sampai pada konteks perilaku menjadi nasabah dan berdasar pada hubungan pribadi dengan Tuhan yang berkonsekuensi hasrat untuk berkenan melaksanakan kehendak-Nya dan menjauhi segala larangan-Nya hingga membuat keputusan untuk beralih ke perbankan syariah.

Ketiga, variabel aksesibilitas berpengaruh positif dan signifikan terhadap perilaku nasabah perbankan konvensional beralih ke perbankan syariah. Salah satu faktor eksternal yang mengarah pada derajat kemudahan yang dicapai oleh individu terhadap lokasi dan pelayanan bank syariah telah terbukti sangat mempengaruhi perilaku nasabah perbankan konvensional beralih ke perbankan syariah dikarenakan sangat membantu nasabah untuk memenuhi kebutuhannya.

Keempat, variabel program ekstra kurikuler islami dalam penelitian ini tidak ditemukan pengaruhnya terhadap perilaku nasabah perbankan konvensional beralih ke perbankan syariah. Hal ini bisa terjadi diduga karena dipengaruhi oleh tingkat kedisiplinan dan keaktifan dalam mengikuti program tersebut 
masih sangat rendah, sehingga sasaran program tersebut yang ditujukan untuk pembentukan akhlakul karimah belum sampai pada konteks nasabah, khususnya nasabah perbankan konvensional yang beralih ke perbankan syariah.

\section{Saran}

Berdasarkan hasil penelitian ini terdapat beberapa saran untuk institusi perguruan tinggi dan perbaikan penelitian kedepannya. Pertama, untuk isntitusi perguruan tinggi khususnya program studi akuntansi, diharapkan untuk terus meningkatkan kualitas program dan metode pembelajaran yang mampu meningkatkan religiusitas mahasiswa yang selaras dengan proses pengembangan ilmu pengetahuan, sehingga mahasiswa sebagai sumber daya yang akan menunjang prospek lembaga keuangan syariah di masa yang akan datang menjadi lebih berkualitas.

Kedua, untuk program studi akuntansi di institusi perguruan tinggi yang sebelumnya telah mewajibkan mahasiswanya mengikuti program ekstra kurikuler islami, sebaiknya tetap dilanjutkan disertai dengan kontrol terhadap kedisiplinan dan keaktifan dalam mengikuti program tersebut. Program ekstra kurikuler islami ini sangat penting untuk segi afektiv dan psikomotorik yang akan menunjang segi kognitif dalam sistem perkuliahan.

Ketiga, untuk peneliti selanjutnya, diharapkan mampu melakukan penelitian dengan studi yang memperluas cakupan sampel bukan hanya mahasiswa program studi akuntansi, sehingga keseluruhan data yang diolah dalam penelitian berasal dari responden yang beralih secara penuh dari perbankan konvensional ke perbankan syariah.

\section{REFERENCES}

Abdurahim, Ahim. (2017). “Akuntabilitas Lembaga Keuangan Syariah dalam Perspektif yang Holistis (Kaffah)". Repository Universitas Muhammadiyah Yogyakarta.

Al-Qur'an dan Terjemahannya. (2014). Jakarta: Departemen Agama RI

Ancok, Djamaludin dan Suroso, Fuat Nashori. (2008) Psikologi Islam : Solusi atas ProblemProblem Psikologi. Yogyakarta. Pustaka Pelajar.

Antonio, M. S. (2016). Bank Syariah dari Teori ke Praktik. Jakarta: Gema Insani.
Arifin, Z. (2006). Dasar-Dasar Manajemen bank syariah. Jakarta: Pustaka Alvabet.

Asnawi. (2016). "Faktor-Faktor yang Memengaruhi Minat Nasabah Muslim dan non Muslim untuk Menjadi Nasabah Bank Syariah". Yogyakarta: Skripsi Universitas Muhammadiyah Yogyakarta.

Astutik. (2015). "Pengaruh Kedisiplinan Mengikuti Kegiatan Mentoring Terhadap Akhlak Siswa Kelas IV di SD IT Harapan Bunda Pedurungan Kota Semarang Tahun Ajaran 2014/2015". Eprints Walisongo .

Dianto, S. (2016). "Faktor-Faktor yang Berpengaruh terhadap Minat Masyarakat untuk Menjadi Nasabah Bank Syariah (Studi Empiris pada Masyarakat di Daerah Istimewa Yogyakarta. Yogyakarta": Skripsi FEB Universitas Muhammadiyah Yogyakarta.

Djamaluddin dan Suroso. (2008). Psikologi Islam : Solusi atas Problem-Problem Psikologi. Yogyakarta: Pustaka Pelajar.

Erol Cenginz dan Radi El-Bdour. (2013). "Attitude, Behavior, and Patronage Factors of Bank Customer towards Islamic Bank". Journal of Bank Marketing, Vol.7 Issue: 6, pp. 3137.

Faisal. (2016). "Analisis Faktor-Faktor yang Mempengaruhi Minat Mahasiswa untuk Menjadi Nasabah di Bank Syariah". Yogyakarta: Skripsi Universitas Muhammadiyah Yogyakarta.

Gufron, S. (2015). Edukasi Profesional Syariah, Konsep dan Implementasi Bank Syariah. Jakarta: Renaisan.

Haque, Ahasanul. Jamil Osman dan Ahmad Zaki $\mathrm{Hj}$ Ismail. (2009). "Factor Influences Selectionof Islamic Banking: A Study on Malaysian Customer Preferences". American Journal of Applied Sciences 6 (5) : 922-928. ISSN 1546-9239.

Hendiyana, R. (2015). "Pengaruh Kegiatan Mentoring Terhadap Akhlak Siswa SMA NEGERI 1 PARUNG". Jakarta. Skripsi UIN Syarif Hidayatullah.

Henry, A. (1998). Measuring Brand Equity Across Product and Market. New York: The Free Press.

Hidayat, R. (2009). "Pengaruh Kualitas Layanan, Kualitas Produk dan Nilai Nasabah Terhadap Kepuasan dan Loyalitas Nasabah Bank Mandiri". Jurnal Manajemen dan Kewirausahaan . 
Ilyas, Y. (2014). Kuliah Akhlaq. Yogyakarta: Lembaga Pengkajian dan Pengamalan Islam (LPPI).

Jalaluddin. (2010). Psikologi Agama. Jakarta: PT. Raja Grafindo Persada.

Jerry, C. Oleson dan J. Paul Peter. (2000). Perilaku Konsumen. Jakarta: Bina Rupa Aksara.

Juanda, dan Ilham Maulana Saud. (2016). Pendampingan Agama Islam Program Studi Akuntansi Fakultas Ekonomi dan Bisnis Universitas Muhammadiyah Yogyakarta. Yogyakarta.

Kariyoto. (2013). Akuntansi dalam Perspektif Syariah Islam. Jurnal Jibeka , 44-51.

Kasmir. (2012). Dasar-Dasar Perbankan. Jakarta: PT Grafindo Persada.

Keaveney, Susan M. (1995). Customer Switching Behavior in Service Industries: An Explanatory Studi. Journal of Marketing, Vol.559, April, pp. 71-82

Kotler. (2004). Marketing Management. New Jersey: Prentice Hall, Inc.

Kusumo, Y. A. (2008). "Analisis Kinerja Keuangan Bank Syariah Mandiri Periode 2002-2007 (dengan Pendekatan PBI N0. 9/1/PBI/2007)". La_Riba Jurnal Ekonomi Islam Vol. 11, No. $1,110$.

Latifah, N. (2016). "Pengaruh Penguasaan Materi Pendidikan Agama Islam dan Hasil Kegiatan Mentoring Agama Islam terhadap Perilaku Sosial Keagamaan Mahasiswa" . Tesis UIN Sunan Kalijaga .

Lestari, Afli Muflikhah. (2014). "Pengaruh Religiusitas, Produk Bank, Kepercayaan, Pengetahuan dan Pelayanan terhadap Preferensi Menabung pada Bank Syariah (Studi Kasus pada Mahasiswa Fakultas Ekonomi dan Bisnis Universitas Brawijaya Malang)". Jurnal Ilmiah Mahasiswa FEB Universitas Brawijaya Vol.03, No.1.

Ludigdo, U. (2009). "Mengembangkan Kurikulum Akuntansi Berbasis Kewirausahaan, Syariah dan Etika: Sebuah Pengalaman". Universitas Brawijaya .

Lupiyoadi, Rambat. (2001). Manajemen Pemasaran Jasa. Edisi XI. Jakarta: Salemba Empat.

Luthans, F. (2005). Organisational Behaviour : Edisi 10. Yogyakarta: ANDI.

Maesaroh, S. (2014). "Pengaruh Atribut Produk, Harga, Kebutuhan Mencari Variasi dan Ketidakpuasan Konsumen terhadap Keputusan Perpindahan Bank (Brand Switching) pada Merek Krim Wajah di
Yogyakarta". Yogyakarta: Tesis Universitas Muhammadiyah Yogyakarta

Maryani, T. dan U. Ludigdo. 2001. "Survey atas Faktor-Faktor yang Mempengaruhi Sikap dan Perilaku Etis Akuntan". TEMA. Volume II Nomor 1. Maret. P.49-62

Masruroh, A. (2015). "Analisis Pengaruh Tingkat Religiusitas dan Disposible Income terhadap Minat Menabung Mahasiswa di Perbankan Syariah". Perpus.iainsalatiga.ac.id

Muhamad. (2016). Sistem Bagi Hasil dan Pricing Bank Syariah. Yogyakarta: UII Press.

Muhammad. (2005). Permasalahan Agency dalam Pembiayaan Mudharabah pada Bank Syariah di Indonesia. Yogyakarta: UII Yogyakarta.

Najib, M. (2009). "Analisis Konsumen Berpindah Merek (Brand Switcher) pada Bank Syariah dan Bank Konvensional (Studi Kasus Pada Nasabah Di Wilayah Darmaga Bogor)". TAZKIA Islamic Finance $\mathcal{E}$ Business Review Vol.4 No.1 , 125.

Nazaruddin, I., dan Basuki, A. T. (2017). Analisis Statistik dengan SPSS. Yogyakarta: Danisa Media.

Notoatmodjo, S. (2005). Promosi Kesehatan Teori dan Aplikasi. Jakarta: Rineka Cipta.

Pratiwi,D., dan Ritonga,H.D. (2012) "Analisis Minat Menabung Masyarakat pada Bank Muamalat di Kota Kisaran". Jurnal Ekonomi dan Keuangan.

Potter, P.A. dan Perry, A.G. (2005). Buku Saku:Keterampilan dan Prosedur Dasar. Edisi 5. Jakarta:EGC.

Qolby, M. L. (2013). Faktor-Faktor yang Mempengaruhi Pembiayaa pada Perbankan Syariah di Indonesia Tahun 2007-2013. Economics Development Analysis Journal (4) , 372.

Rahmawati, A. (2014). "Pengaruh Persepsi tentang Bank Syariah terhadap Minat Menggunakan Produk di BNI Syariah Semarang". ADDIN, vol. 8, No.1, Feberuari 2014.

Republik Indonesia, Undang-Undang No. 10 Tahun 1998 tentang Perbankan Syariah.

Republik Indonesia, Undang-Undang N0. 7 Tahun 1992 tentang Eksistensi Perbankan.

Republik Indonesia, Undang-Undang No. 21 Tahun 2008 tentang Perbankan Suyariah.

Risky, Z. A. (2015). "Faktor-Faktor yang Berpengaruh pada Preferensi untuk Memilih Perbankan Syariah". 
Yogyakarta: Skripsi Universitas Muhammadiyah Yogyakarta.

Rohman, Abdul. (2009). "Pengaruh Implementasi Sistem Akuntansi, Pengelolaan Keuangan Daerah terhadap Fungsi Pengawasan dan Kinerja Pemerintah Daerah (Survey pada Pemda di Jawa Tengah)". Jurnal Akuntansi. Universitas Sebelas Maret. Surakarta.

Ruswandi. (2007). Manajemen Mentoring. Bandung: Syaamil.

Sahlan, A. (2011). "Religiusitas Perguruan Tinggi:Potret Pengembangan Tradisi Keagamaan di Perguruan Tinggi Islam". repository.uin-malang.ac.id.

Schiffman, dan Kanuk. (2002). Customer Behavor 7th Ed. New Jersey: Prentice Hall.

Suhardiyanto. 2001. Pendidikan Religiusitas. Yogyakarta: Kanisius.

Suwarman, Ujang (2004) Riset Pemasaran dan Konsumen, Seri 2. Bogor: PT. Penerbit IPB Press.

Thouless, R.H. (1995). Pengantar Psikologi Agama. Jakarta: PT. Raja Grafindo Persada.

Tyas, R.R. dan A Setiawan. (2012). "Pengaruh Lokasi dan Kualitas Pelayanan terhadap Keputusan Nasabah untuk Menabung di BMT Sumber Mulia Tuntang". Muqtasid: Jurnal Ekonomi dan Bisnis.

Trup, Van. Hans C.M, Wayne D. Hoyer, and J. Jeffrey Inman. (1996). "Why Switch? Product Category-Level Explanations for True Variety-Seeking Behavior". Journal of Marketing Research, Augustus, pp.281292.

Wibowo, E. (2005). Mengapa Memilih Bank Syariah. Bogor: Ghalia Indonesia.

Widiyanti, N. (2011). "Faktor-Faktor yang Berpengaruh terhadap Minat untuk Berinvestasi pada Bank Syariah (Studi Empiris pada Mahasiswa Akuntansi Perguruan Tinggi Islam di D.I.Y)". Yogyakarta: Skripsi FE Universitas Muhammadiyah Yogyakarta.

Wulandari, Siti Zulaikha dan Dwiwyati Astogini. (2014). "Aspek Religiusitas dalam Keputusan Pembelian Produk Halal (Studi tentang Labelisasi halal pada Produk Makanan dan Minuman Kemasan)". JEBA, Vol. 13, No.1, Maret 2011.

Yaya, Rizal. Aji E.M. dan Ahim Abdurahim (2014). Akuntansi Perbankan Syariah Teori dan
Praktik Kontemporer. Jakarta Selatan: Salemba Empat.

Yuliadi, I. (2007). Ekonomi Islam: Filosofi, Teori dan Implementasi. Yogyakarta: LPPI-UMY. 